\title{
Giant Plagioclase Basalt from THE EASTERN AND WESTERN DECCAN VOLCANIC PROVINCE: PETROGENETIC IMPLCATIONS
}

VIRINDER PAL SINGH, J. P. SHRIVASTAVA* AND PRAMOD KUMAR

*Department of Geology, Univcersity of Delhi, Delhi 110007 , India

\begin{abstract}
Giant plagioclase basalt (GPB) present in the Deccan Traps, formed in a deeper magma chamber provides insight into magma mixing and fractionation processes. Previously, GPBs has been reported from kalsubai subgroup of Western Ghats and studies were restricted to establish GPB as a marker horizon; however, their detailed chemico-mineralogical attributes still remain uncertain. Recently one GPB flow from northeast corner of DVP has also been reported. In present work we are reporting two GPB flows from the Koyna Nagar, Maharashtra for the first time, GPB from eastern DVP (Kevlari Kalana and Jhabua) along with the GPB of Kalsubai subgroup of Western DVP. The BGRL provided $\mathrm{KBH}-1$ core for the present physical examination and sampling purpose. The bore hole (KBH-1, N17 24 ' 6"; $\left.\mathrm{E} 73^{\circ} 45^{\prime} 8^{\prime \prime}\right)$ is located in the Rasati village near Koyna $(\sim 2.5 \mathrm{~km}$ SSW of Koyna Dam reservoir) area in the southern DVP. It is unique of its kind that provides fresh lava flow core samples to study flow-by-flow continuous record of a deep sub-surface Deccan volcano-sedimentary sequence extending up to the Achaean basement. The eastern GPB lava flows of the north-eastern part of the DVP are located at Kevlari Kalan village (long. $23^{\circ} 27^{\prime} \mathrm{E}$ and lat. $78^{\circ} 42^{\prime} \mathrm{N}$ ) in Kesli tehsil of the Sagar district, Madhya Pradesh. This GPB flow is exposed on the ground level elevations on the surrounding hills for $15 \mathrm{sq}$. $\mathrm{km}$ in the topo-sheet No. 55I/11 and extends further to the south.

$\mathrm{MgO}$ content varied from $4.50-5.00 \%$, which is similar to that of GPBs of Kalsubai Subgroup, but it is less when compared to Sagar GPB which show $6.13 \% \mathrm{MgO}$ content.
\end{abstract}

Keywords: Basalt; Giant Plagicolase Basalt; Deccan volcanic province. 